УДК 321.6/.8-057.341

DOI https://doi.org/10.32837/apfs.v0i26.909

В. В.Стрелков

ORCID ID: 0000-0001-8436-3260

аспірант кафедри політологї, управління та державної безпеки

Волинського національного університету ілені Лесі Українки

\title{
КОНФІГУРАЦІЯ ДЕЛЕГІТИМАЦІЙНОГО ПРОЦЕСУ ТА ДЕІНІЦІАЛІЗАЦІЯ ПРЕЗИДЕНТСЬКОЇ ВЛАДИ
}

Постановка проблеми. За час незалежності української держави ми могли спостерігати яскраві вияви делегітимації політичних інститутів суспільства: інституту виборів під час Помаранчевої революції 2004 року, інституту президентства під час подій Революції гідності 2014 року. Підбили підсумки делегітимації української політичної еліти як класу президентські вибори 2019 року. Процеси делегітимації президентської влади та екстраполяція впливу делегітимаційних політичних технологій на інститут президентства створюють серйозні проблеми та загрози для стабільного розвитку політичної системи України. Наведені вище факти актуалізують необхідність дослідження процесу делегітимації президентської влади та політичних технологій, які застосовують для управління ним.

Аналіз останніх досліджень i публікацій. Актуальними в контексті цього дослідження є праці українських науковців I. Забеліної, С. Ставченко, Ю. Мацієвського, Г. Щедрової, Р. Ключника, у яких висвітлюється проблематика політичних криз, зокрема кризи легітимності політичної влади. Для дослідження технологій оцінки ефективності та контролю за застосуванням технологій делегітимації президентської влади на етапі деініціалізації були корисними праці зарубіжних науковців М. Догана, Ф. Хастінгса, Б. Краснова, Д. Віртліна.

Виділення не вирішених раніше частин загальної проблеми. Легітимність як політичне явище та наукова категорія цікавить багатьох дослідників. Однак, незважаючи на наукову необхідність у дослідженні закономірностей перебігу процесу втрати легітимності, ми спостерігаємо певне уникнення наукового впровадження концепту делегітимації у політичну науку.

Мета статті - дослідити особливості конфігурації процесу делегітимації та деініціалізації президентської влади як етапів делегітимаційного процесу. Для досягнення цієї мети ми вирішили такі завдання: виявити сутнісні характеристики кризи легітимності як політичного явища, встановити типи криз легітимності; дослідити технології управління процесом делегітимації президентської влади на етапі деініціалізації, пов'язані з оцінкою ефективності та контролем за реалізацією делегітимаційних політичних технологій.
Виклад основного матеріалу дослідження. На етапі конфігурацї̈ делегітимаційний процес набуває чітких форм у вигляді кризи легітимності президентської влади. Аналіз кризи легітимності як політичного явища необхідно проводити в рамках визначених самим поняттям «криза» (від грец. "krisis" - «вихід, закінчення, суд, справедливе покарання»). Великий тлумачний словник української мови визначає кризу як різку зміну звичайного стану речей, злам, загострення становища [1, с. 586]. Очевидно, що поняття «криза» політична наука запозичила із медичної галузі, в якій воно означало різкий, крутий перелом, важкий перехідний стан.

Криза - це природна фаза розвитку будь-якої системи, зона біфуркації; момент дезорганізації системи, чинник iї організації, самоорганізації. Суть політичної кризи полягає у тому, що влада не в змозі керувати певними процесами. Політична криза може розглядатися як один з етапів політичного процесу, як підсумок політичного протиборства і розвитку соціально-політичного конфлікту [2, с. 346]. Сутність політичної кризи можна трактувати як крайнє загострення протиріч у політичній системі, яке загрожує ії стабільності.

Політична енциклопедія визначає політичну кризу як етап у розвитку політичного об'єкта (держави, влади, конкретної політики, парламенту, режиму, політичної системи, уряду), який характеризується порушенням рівноваги однієї чи кількох базових підсистем у процесі їхнього функціонування, внаслідок чого змінюється сутність об'єкта, порушується регулярність політичної взаємодії. Вона може виявлятися у зміні не тільки стану об'єкта, а й його характеристик (якостей). Тому криза легітимності як один із видів політичної кризи є результатом розбалансування мети та цінностей правлячого режиму з уявленнями щодо них більшої частини громадян [3, с. 373].

Політична криза є масовим відхиленням від прийнятих у відповідній системі моделей поведінки, дисфункцією політичних інститутів, невідповідністю системних реакцій на вимоги середовища, втратою легітимності правлячою елітою та відповідними структурами влади. До такого висновку дійшов С. Ставченко [4, с. 71].

Ю. Мацієвський вважає, що зовнішнім виявом кризи $€$ нездатність політичного керівництва 
приймати ефективні рішення, утримувати контроль над ходом політичного процесу, тому часу на прийняття рішення за кризової ситуації стає значно менше, а кількість проблемних питань, по яких мають бути прийняті управлінські рішення, збільшується лавиноподібно. На його думку, криза є складним явищем, для виникнення якого необхідно, щоб збігалися достатні та необхідні умови. Достатніми умовами кризи є політична нестабільність і напруга, необхідною умовою є неефективність рішень і діяльнісна неспроможність політичного керівництва у нестабільній ситуації.

Криза є суб'єктивно зумовленим явищем вона може бути спровокована або створена штучно. Криза може бути подолана ефективними діями політичного керівництва або ж поглиблена, що може призвести до колапсу чи розпаду об'єкта [5, с. 158-159]. На необхідності визначення сфери політичних відносин (або їх сукупностей) is домінуючою нестабільністю для з'ясування природи кризових явищ і визначення механізмів їх подолання наголошує Г. Щедрова. За твердженням вченої, системна політична криза завжди має домінанту нестабільності - політичні інститути чи сфери політичного життя, які переживають занепад, стагнацію чи дисфункцію у той чи інший період [6, с. 10].

Р. Ключник зауважує, що криза може нести в собі не тільки негатив, але й певні позитивні зміни для політичної системи. Він наголошує, що криза є важливим чинником розвитку політичної системи, причому їі вплив може бути як негативним, так і позитивним. Вона може не лише гальмувати чи зупиняти розвиток політичної системи, але й надавати нових імпульсів, сприяти якісній трансформації політичних інститутів чи системи загалом. Криза в сучасній політичній науці уже не розглядається як суто негативне чи небезпечне явище, вона є радше свого роду випробуванням, через яке проходить будь-яка система [7, с. 105].

Криза легітимності визначається як стрес, який відчуває конституйована структура та виконавча влада, що виникає через відмінності в поглядах 3 приводу авторитету влади як такої [8, с. 112]. Російські вчені А. Глухова та В. Рахманін визначають кризу як ситуацію складного перехідного стану, повороту, поворотного пункту, яка потребує вирішення [9, с. 211-212]. На їхню думку, для того, щоб утворити ситуацію кризи легітимності, необхідно похитнути уявлення, символи віри, відповідно до яких влада володіє правом приймати рішення, які громадяни зобов' язані виконувати [9, с. 215].

Кризу легітимності можна розглядати як кризу відносин панування та підкорення між суб'єктом та об'єктом політичного впливу, внаслідок якої суб’єкт втрачає здатність здійснювати вплив на об’єкт. Характерним для кризи легітимності є оскарження правомірності політичної влади, фрагментованість політичної влади та наявність численних «центрів сили». Криза легітимності може відбуватися на макро- та мікрорівні. Макрорівень складають дві великі групи криз: внутрішньополітичні та зовнішньополітичні. Мікрорівень представлений такими підрівнями криз: загальний (в межах усього громадянського суспільства), регіональний (у межах певних адміністративних одиниць), груповий (в межах етнічних, національних, класових груп інтересів), особистісний (у свідомості окремо взятого індивіда).

Делегітимація президентської влади може стати наслідком втрати функціональних здібностей самого інституту президентства, як трапилося у 1991 році із президентом СРСР М. Горбачовим. Розпад СРСР підтвердив нелегітимність президента держави. Тому можна стверджувати, що криза легітимності президентської влади ініціюється нездатністю президента виступати гарантом політичного порядку в державі.

У контексті делегітимації президентської влади пропонуємо розрізняти такі типи криз легітимності: інституційна, нормативно-процедурна, суспільно-політична, криза міжнародних зносин. Інституиійна криза легітилності пов'язана із проблемами функціонування інститутів державної влади. Вони можуть виявлятися у формі незгоди із наявним обсягом повноважень, закріплених за інститутом президента, конфліктному характері відносин з приводу перерозподілу владних повноважень між гілками влади, не визнанні президентської вертикалі влади та їі ієрархічної структури «ролей» у структурах бюрократичного апарату та «на місцях» (регіональними представництвами президентської вертикалі - місцевими державними адміністраціями, губернаторами; органами та інститутами місцевого самоврядування - обласними та районними радами, об'єднаними територіальними громадами), що може виявлятися шляхом саботажу виконання президентських рішень.

За умов інституційної кризи легітимності не можливо досягнути узгодженої взаємодії між політичними інститутами. Наслідком цього $є$ неефективне виконання політичними інститутами своїх функцій та обов'язків, що призводить до зниження підтримки правлячого режиму.

Норлативно-процедурна криза легітилності може виявлятися у делегітимації інституту виборів, дисфункції механізму стримувань і противаг, правовому нігілізмі, електоральному абсентеїзмі.

Суспільно-політична криза легітилності відбувається у площині взаємодії президентської влади $з$ громадянським суспільством. Вона пов' язана із суспільним визнанням або невизнанням президентської влади, грунтується на недовірі з боку населення, відсутності громадської підтримки. 
Відповідно до теорії С. Ліпсета криза легітимності виявляється у нездатності політичної системи підтримувати у людей впевненість у тому, що існуючі політичні інститути є найбільш прийнятними для суспільства [10, с. 77].

Криза легітилності у міжнародних зносинах відображається шляхом невизнання легітимності президента на міжнародній арені, лідерами інших держав і міжнародними організаціями. Вона може виявлятися у формі санкцій, міжнародної ізоляції.

Необхідно звернути увагу на те, що пропоновану типологію нечасто можна зафіксувати у чистому вигляді на практиці, оскільки для делегітимаційного процесу характерна динамічність перебігу, через яку він швидко поширюється і переходить на різні рівні кризових явищ. Так, криза зовнішньополітичних міжнародних зносин може впливати на певні аспекти внутрішньої політики. Внутрішньополітична криза легітимності, яка може мати форму інституційної, нормативно-правової, суспільно-політичної кризи або бути комбінацією із цих форм, впливає на авторитет, правомочність президента та визнання його легітимності серед міжнародної спільноти.

На етапі деініціалізацї відбувається відчуження президентської влади. Під час цього етапу застосовуються технології управління делегітимаційним процесом, спрямовані на роботу з інформаційним середовищем політичної системи. Метою такої роботи є легітимація наступного очільника держави. Термін «деініціалізація» запозичений із мови програмування Swift, у якій він означає «відновлення середовища, яке передувало запуску процесу» [11]. На етапі деініціалізації здійснюється оцінка ефективності та контроль за результатами застосування делегітимаційних технологій.

Для емпіричної перевірки та оцінки легітимності М. Доган пропонує у соціологічних опитуваннях ставити питання 3 трьома варіантами відповідей, які відображають сутність суперечок про легітимність. Спираючись на його методику, стосовно президентської влади ці питання можна сформулювати так: 1) «Я визнаю чинного президента та прийняті ним рішення і вважаю себе зобов'язаним їх виконувати»; 2) «Я бачу багато недоліків у роботі та рішеннях чинного президента, але буду їх виконувати через віру у можливість поступового вдосконалення наявної політики президента»; 3) «Я повністю не визнаю владу чинного президента та рішення, які він приймає, відмовляюся їх виконувати і бачу єдине рішення в докорінних соціально-політичних змінах» .

На думку науковця, перший варіант відповіді передбачав би наявність віри в легітимність президента. Другий - свідчив би про наявність переконання у тому, що, незважаючи на всі його недоліки, чинний президент є кращим із можли- вих, а політика, яку він здійснює, піддається вдосконаленню. Третя відповідь вказувала б на те, що чинний президент сприймається як нелегітимний $[12$, c. 150$]$.

Аналогічні три варіанти відповідей, але вже стосовно правлячих режимів, були запропоновані в дослідженні Ф. Хастінгса, у якому зібрані емпіричні дані про ставлення громадськості до правлячих режимів різних країн. У більшості країн пропорція громадян, які у 1981 році обрали третій варіант відповіді, була невеликою: $9 \%$ у США, $3 \%$ у Німеччині, $7 \%$ у Канаді, $10 \%$ в Австралії. В окремих країнах пропорція таких громадян була відносно великою: $26 \%$ у Франції, $24 \%$ у Великобританії, а в Індії вона досягла рівня в $41 \%$, який, на думку авторів, ставить під сумнів легітимність правлячого режиму [13, с. 512].

Б. Краснов для оцінки легітимності об'єкта пропонує використовувати такі показники: рівень примусу, який застосовується для втілення політики у життя; наявність спроб повалення уряду або лідера; сила вияву громадянської непокори, а також результати виборів, референдумів, масовість демонстрацій на підтримку влади (опозиції) $[14$, c. 84$]$.

З огляду на те, що комунікаційний інформаційний контент є центральним елементом технології делегітимації президентської влади, для контролю за досягненням прогнозованих наслідків впливу комунікації на громадську думку доцільно буде використовувати технології комп'ютерного прогнозування, запропоновані Д. Віртліном. Принцип дії цих технологій полягає у створенні карти ієрархії цінностей - Hierarchial Values Map (далі HVM) [15, с. 142]. Він дав цим технологіям назву «політична інформаційна система» - Political Information System (далі - PINS) [15, с. 40].

Для контролю за результатами застосування делегітимаційних технологій ми рекомендуємо застосовувати такі методи: активне спостереження із визначенням тригерів, відповідним і своєчасним реагуванням на сигнали зовнішнього середовища; експертиза - оцінка із залученням фахівців, лідерів громадської думки, представників 3MI; визначення індикаторів ефективності застосованих технологій; контент-аналіз технічних звітів виконавців; медіа-аналіз інформаційного простору на предмет реакції аудиторії на комунікацію, дослідження результатів декодування закладеного у комунікацію контенту цільовою аудиторією; моніторинг соціальних мереж; фокус-групи й контрольні соціологічні заміри. Такий контроль є надважливим, адже саме успішний контроль на етапі деініціалізації дозволяє уникнути негативного впливу на інститут президентства та в межах існуючого конституційного ладу забезпечити легітимне правонаступництво на цій посаді наступному народному обранцю. 
Політтехнологи часто нехтують заходами та інструментами контролю за застосуванням делегітимаційних технологій, що призводить до недбалого управління делегітимаційним процесом на етапі деініціалізації. Тому виникає необхідність змінювати конституційний лад у державі під наступного президента через неймовірно низьку довіру до інституту президента за існуючих правил політичної гри. Як приклад можна наводити як зарубіжні кейси, так і прецеденти українського політичного процесу - конституційні реформи після президентських виборів у Білорусі 2020 року та в Україні 2014 року із подальшою втечею президента із країни в останньому випадку.

Висновки та перспективи подальших пошуків. Делегітимація президентської влади на етапі конфігурації набуває форми кризи легітимності, внаслідок цього президент перестає отримувати політичну підтримку від джерел легітимації (суспільства, внутрішніх політичних акторів, міжнародної спільноти). Втрата такої підтримки призводить до змін у політичній системі, які можуть відбуватися як мирним шляхом, так і з загостренням політичної боротьби із подальшим утворенням конфліктних ситуацій.

Етап деініціалізації президентської влади залишається найменш дослідженим. У науковій літературі спостерігається брак інформації про особливості цього етапу делегітимаційного процесу та про можливості застосування політичних технологій для керування ним. Вбачаємо у цьому перспективу для більш поглибленого дослідження етапів делегітимаційного процесу в контексті застосування політичних технологій для управління ним.

\section{Jimepamypa}

1. Великий тлумачний словник сучасної української мови / за ред. В.Т. Бусела. Київ, Ірпінь : ВТФ «Перун», 2005. 1728 c.

2. Забеліна І.О. Поняття та сутність політичних криз: історико-бібліографічний аналіз. Актуальні проблеми політики : зб. наук. пр. / за ред. С.В. Ківалова. Одеса : НУ ОЮА, 2013. Вип. 49. С. 344-353.

3. Політична енциклопедія / за ред. Ю.А. Левенця. Київ : Парламентське видавництво, 2011. 808 с.

4. Ставченко С.В. Стабільність i кризовість у соціально-політичному розвитку. Грані. 2015. № 4. С. $69-73$.

5. Мацієвський Ю.В. Політична криза: теоретичний аналіз. Наукові записки Національного університету «Острозька академія». Серія: Політичні науки. 2008. Вип. 3. С. 146-161.

6. Щедрова Г.П. Політична криза: структурно-функціональний аспект. Гілея : науковий вісник. 2018. Вип. 139. С. 7-11.

7. Ключник P.М. Криза у політичній системі: проблеми методології дослідження. Вісник Дніпропетровського університету. Серія: Філософія. Соиіологія. Політологія. 2015. № 2. С. 105-111.
8. Демократизация и образы национализма в Российской Федерации 90-х годов / Дробижева Л.М. и др. Москва : Мысль, 1996. 382 с.

9. Глухова А.В., Рахманин В.С. Политическая конфликтология : учеб. пособ. Воронеж : Воронеж. гос. ун-т, 2002. 295 с.

10. Lipset S.M. Political man: The social bases of politics. New-York, Garden City : Doubleday, 1960. 432 p.

11. Англо-русский словарь по информационным технологиям / сост. Л.Г. Суменко. Москва : ГП ЦНИИС, 2003. 782 c.

12. Доган М. Легитимность режимов и кризис доверия. Социологические исследования. 1994. № 6. C. $147-156$.

13. Index to International Public Opinion, 1980-1981 / eds. P. Hastings, E. Hastings. Westport, Connecticut : Greenwood Press, 1982. 584 p.

14. Краснов Б.И. Теория власти и властных отношений. Социально-политический журнал. 1994. № 3(6). C. 76-84.

15. Wirthlin D. The greatest communicator. What Ronald Reagan taught me about politics, leadership, and life. New-York : Hoboken, 2004. 224 p.

\section{Анотація}

Стрелков В. В. Конфігурація делегітимаційного процесу та деініціалізація президентської влади. Стаття.

Криза легітимності інститутів політичної влади $€$ актуальною проблемою сучасного політичного процесу. Особливо гостро такі проблеми відчуваються у державах, які знаходяться на етапі демократичного транзиту. Легітимність як політичне явище та наукова категорія є предметом зацікавленості широкого кола дослідників. Однак, незважаючи на наукову необхідність у дослідженні закономірностей перебігу процесу втрати легітимності, ми спостерігаємо певне уникнення наукового впровадження концепту делегітимації у політичну науку. 3 огляду на відсутність великої кількості наукових праць, присвячених проблемам делегітимації політичної влади, вважаємо за необхідне надати визначення поняття «делегітимація» - це процес відчуження політичної влади від джерел легітимності, внаслідок якого відбувається втрата суб'єктності стосовно них.

У статті розглядається теоретична концепція конфігурації делегітимаційного процесу. У випадку відсутності адекватної та своєчасної політтехнологічної реакції на делегітимаційний процес він може призвести до деініціалізації президентської влади.

Дослідження процесу делегітимації президентської влади та етапів його перебігу є важливим у контексті сприяння забезпеченню стабільності і сталого розвитку політичної системи та її інститутів. У рамках цього дослідження ми розглянули кризу легітимності як політичне явище. Встановили особливості впливу кризи легітимності на політичну систему. Запропонували розрізняти такі типи кризи легітимності президентської влади: інституційна, нормативно-процедурна, суспільно-політична, міжнародних зносин. Дослідили технології, які застосовують для управління процесом делегітимації президентської влади на етапі деініціалізації. Визначили найбільш релевантні методи для оцінки 
ефективності та контролю за результатами застосування делегітимаційних політичних технологій.

Ключові слова: делегітимація, криза легітимності, президентська влада, делегітимаційний процес, політичні технології.

\section{Summary}

Strelkov $V . V$. Configuration of the delegitimation process and deinitialization of presidential power. Article.

The crisis of legitimacy of institutions of political power is an urgent problem of the modern political process. Such problems are especially acute in countries in the process of democratic transit. Legitimacy, as a political phenomenon and a scientific category, is the subject of interest of a wide range of researchers. However, despite the scientific need to study the patterns of the process of loss of legitimacy, we see some avoidance of scientific implementation of the concept of delegitimation in political science. Given the lack of a large number of scientific papers on the problems of delegitimation of political power, we consider it necessary to provide a definition here: delegitimation is the process of alienation of political power from sources of legitimacy, resulting in loss of subjectivity.
The article considers the theoretical concept of the configuration of the delegitimation process. In the absence of an adequate and timely political-technological response to the delegitimation process, it may lead to the deinitialization of presidential power.

The study of the process of delegitimation of presidential power and the stages of its course is very important in the context of promoting stability and sustainable development of the political system and its institutions. In this scientific research, we considered the crisis of legitimacy as a political phenomenon. The peculiarities of the impact of the crisis of legitimacy on the political system have been established. It was proposed to distinguish the following types of crisis of legitimacy of presidential power: institutional, normative-procedural, socio-political, international relations. Researched the technologies used to manage the process of delegitimation of presidential power at the stage of deinitialization. The most relevant methods for assessing the effectiveness and monitoring the results of the use of delegitimation political technologies have been identified.

Key words: delegitimation, crisis of legitimacy, presidential power, delegitimation process, political technologies. 